\title{
PENGARUH PENGGUNAAN TEKNOLOGI PEMBELAJARAN BLENDED LEARNING TERHADAP HASIL BELAJAR MENULIS TEKS FUNGSIONAL PENDEK BAHASA INGGRIS
}

\author{
Nurul Badriyatul Muthoharoh \\ Program Studi Teknik Informatika - FT-MIPA \\ Universitas Indraprasta PGRI \\ nurul.badriah1002@gmail.com
}

\begin{abstract}
Abstrak
Tujuan dari penelitian ini adalah untuk mengidentifikasi masalah dan kesulitan apa saja yang di alami oleh para siswa ketika mereka belajar menulis teks fungsional pendek bahasa Inggris, mengetahui apakah teknologi pembelajaran Blended Learning mempengaruhi hasil belajar menulis teks fungsional pendek bahasa inggris dan mengetahui apakah terdapat pengaruh penggunaan teknologi pembelajaran blended learning terhadap hasil belajar menulis teks fungsional pendek bahasa Inggris pada siswa kelas VII SMPN 98 Jakarta Selatan. Penulis mengadakan penelitian ini dengan menggunakan metode eksperimen dengan menggunakan teknik pengambilan sampel secara acak (Random Sampling). Sampel terdiri dari 70 siswa yang terdiri dari 2 kelompok, yaitu kelompok eksperimen dan kelompok kontrol. Instrumen penelitian ini adalah tes akhir yang berjumlah 10 butir soal essai. Teknik analisis data yang digunakan adalah "uji-t" pada taraf signifikan $\alpha=0.05$. Berdasarkan hasil menunjukkan bahwa terdapat pengaruh yang signifikan terhadap penggunaan teknologi pembelajaran Blended Learning terhadap hasil belajar menulis teks fungsional pendek bahasa Inggris pada siswa kelas VII SMPN 98 Jakarta Selatan.
\end{abstract}

Kata Kunci: Hasil Belajar, Menulis Bahasa Inggris, Teknologi Pembelajaran Blended Learning, Teks Fungsional Pendek, dan Pengaruh.

\begin{abstract}
The aims of this research is to identify the problems and difficulties experienced by students when they learn to write English short functional text, know the effect of Blended Learning technology towards learning outcomes in writing English short functional text and know the influence of using blended learning technology towards learning outcomes in English short functional text in the seventh grade students of SMPN 98 South Jakarta. This research method was an experimental method using random sampling technique (Random Sampling). The sample consisted of 70 students consisting of two groups: the experimental group and the control group. The instrument of this study is the final test which amounted to 10 items essay. Data analysis technique used "t-test" on a significant level $\alpha=0: 05$. Based on the results shows that there is a significant influence of using Blended Learning technology towards learning outcomes English short functional text in the seventh grade students of SMPN 98 South Jakarta.
\end{abstract}

Keywords: Learning Outcomes, English Writing, Blended Learning Technology, Short Functional Text, and Influence.

\section{PENDAHULUAN}

Perkembangan ilmu pengetahuan dan teknologi berkembang begitu cepat, sehingga menuntut sumber daya manusia yang bisa tanggap akan perkembangan tersebut. Dalam dunia pendidikan, perkembangan teknologi sangat mempengaruhi akan sebuah model pembelajaran yang berdasarkan teori-teori belajar yang ada.

Dalam proses pembelajaran, guru sebagai salah satu sumber daya manusia tentunya memegang peranan penting 
akan keberhasilan dan keefektifan sebuah pendidikan. Keberhasilan seorang guru dalam menyampaikan suatu materi pelajaran, tidak hanya dipengaruhi oleh kemampuannya (komptensi guru) dalam menguasai materi yang akan disampaikan. Akan tetapi ada faktor-faktor lain yang harus dikuasainya sehingga ia mampu menyampaikan materi secara profesional dan efektif. Faktor-faktor tersebut sudah diatur dalam UndangUndang Guru dan Dosen No. 14 Tahun 2005 Bab IV Bagian Kesatu Pasal 10 yakni, "Kompetensi guru sebagaimana dimaksud dalam Pasal 8 meliputi kompetensi pedagogik, kompetensi kepribadian, kompetensi sosial, dan kompetensi profesional yang diperoleh melalui pendidikan profesi."

Kompotensi-kompotensi tersebut dijabarkan dalam Peraturan Pemerintah No. 16 Tahun 2007. Dalam kompetensi pedadogik, salah satunya pointnya adalah seorang guru harus menguasai teori belajar dan prinsip-prinsip pembelajaran yang mendidik. Penguasaan meliputi kompetensi guru dalam menerapkan berbagai pendekatan, strategi, metode, dan teknik pembelajaran yang mendidik secara kreatif dalam mata pelajaran yang diampu.

Belajar adalah sebuah proses di mana terdapat perubahan perilaku dari seseorang melalui latihan baik itu latihan di laboratorium (tempat yang dikhususkan untuk proses belajar mengajar, kelas) maupun latihan di lingkungan alamiahnya. Beranjak dari konsep belajar yang menjelaskan tentang perilaku, ada dua kelompok/aliran teori belajar, yakni aliran behavioristik dan aliran kognitif.

Salah satu teori belajar dari aliran kognitif yang menjadi terkenal saat ini untuk menghasilkan efektifitas dan keberhasilan guru di kelas adalah teori belajar konstruktivis. Menurut teori ini belajar bukanlah hanya sekedar menghafal akan tetapi belajar sebagai proses mengkonstruksi atau membangun pengetahuan melalui pengalaman.

Teori-teori belajar tersebut awalnya dilakukan dalam sebuah pembelajaran langsung atau tradisional yang belum menggunakan alat atau media pembelajaran melalui aplikasi ICT (Information, Comunication and Technology). Akan tetapi dengan berkembangnya ICT memunculkan berbagai pembelajaran secara online atau web-school atau cyber-school yang menggunakan fasilitas internet mengundang banyak istilah dalam pembelajaran. Banyak definisi tentang pembelajaran yang menggunakan internet, seperti, online learning, distance learning, web-based learning dan, e-learning. Hal tersebut banyak membuat orang menjadi bingung dengan istilah-isitlah tersebut, maka penulis memberikan definisi untuk masingmasing istilah di atas sebagai berikut:

1. E-learning sebagian besar berkaiatan dengan kegiatan yang melibatkan komputer dan jaringan interaktif secara bersamaan. Artinya, komputer tidak perlu menjadi elemen pusat dalam kegiatan atau menyediakan isi pembelajaran, tetapi komputer dan jaringan harus memegang keterlibatan besar dalam kegiatan pembelajaran.

2. Online learning dihubungkan dengan konten yang siap diakses pada komputer. Konten tersebut mungkin di Web atau internet, atau hanya diinstal pada CD-ROM atau hard disk komputer.

3. Distance learning melibatkan interaksi pada jarak jauh antara instruktur dan peserta didik, dan memungkinkan reaksi instruktur tepat waktu pada peserta didik. Dengan cukup memposting atau 
menyiarkan materi pembelajaran untuk peserta didik bukan merupakan pembelajaran jarak jauh. Instruktur harus terlibat dalam menerima umpan balik dari peserta didik.

4. Web-based learning dihubungkan dengan materi pembelajaran yang disampaikan dalam Web Browser, termasuk ketika materi dikemas dalam CD-ROM atau media lain.

Dalam sistem pembelajaran jarak jauh (distance learning), metode yang digunakan adalah metode pengajaran dimana aktivitas pengajaran dilaksanakan secara terpisah dari aktivitas belajar. Sebagian besar karena siswa bertempat tinggal jauh atau terpisah dari lokasi lembaga pendidikan. Sebagian karena alasan sibuk sehingga siswa yang tinggalnya dekat dari lokasi lembaga pendidikan tidak dapat mengikuti proses pembelajaran di lembaga tersebut.

Sebagaimana sistem pembelajaran langsung atau konvensional, sistem pembelajaran jarak jauh juga membutuhkan sarana prasarana penunjang pendidikan, agar tujuan umum pendidikan bisa diwujudkan sesuai dengan jenjang pendidikannya. Salah satu sarana yang yang penting dalam menunjang pembelajaran tersebut adalah sesuatu berbasis ICT (Information, Communication and Technology). Tidak seperti sistem pembelajaran langsung, sistem pembelajaran jarak jauh membutuhkan pengelolaan dan manajemen pembelajaran yang "khusus", baik dari sisi siswa maupun instruktur (guru) agar tujuan pendidikan bisa terwujud. Pendidikan harus fokus pada kebutuhan instruksional siswa.

Dari sisi instruktur (guru), beberapa faktor yang penting untuk keberhasilan sistem pembelajaran jarak jauh adalah perhatian, percaya diri guru, pengalaman, mudah menggunakan peralatan, kreatif, active learning, dan kemampuan menjalin interaksi dan komunikasi jarak jauh dengan siswa. Juga memperhatikan hambatan teknis yang mungkin terjadi, sehingga pembelajaran jarak jauh bisa berlangsung efektif.

Berdasarkan beberapa studi yang ada, penggunaan web dalam pembelajaran umumnya diterapkan di sekolah-sekolah tinggi atau universitas untuk menghasilkan pembelajaran yang efektif dan bermakna. Akan tetapi model pembelajaran berbasis web juga bisa diterapkan di tingkat sekolah dasar dan menengah.

Karena Blended Learning ini merupakan kombinasi dari pembelajaran berbasis web dan pembelajaran tatap muka, maka pembelajaran ini dapat diterapkan pada mata pelajaran apa pun, termasuk mata pelajaran bahasa Inggris untuk kemampuan menulis yang salah satunya dipengaruhi oleh perkembangan ilmu pengetahun dan teknologi yang pesat.

Menulis merupakan suatu keterampilan berbahasa yang dipergunakan untuk berkomunikasi secara tidak langsung, tidak secara tatap muka dengan orang lain. Menulis merupakan suatu kegiatan yang produktif dan ekspresif. Menulis ialah menurunkan atau melukiskan lambanglambang grafik yang menggambarkan suatu bahasa yang dipahami oleh seseorang, sehingga orang-orang lain dapat membaca lambang-lambang grafik tersebut jika mereka memahami bahasa dan gambaran grafik itu.

Model pembelajaran Blended Learning dalam pembelajaran bahasa Inggris terdiri atas 4 tahapan instruksional, yakni tahapan satu (presenting information) dan tahapan kedua (guiding the learner) menggunakan pembelajaran tatap muka 
(face to face learning), sedangkan tahapan ketiga (practicing) dan tahapan keempat (assesing learning) menggunakan pembelajaran berbasis web (web-based learning).

\section{TINJAUAN PUSTAKA Hakikat Pengaruh}

Pengertian pengaruh menurut

Kamus Besar Bahasa Indonesia (2001:849) yaitu: "daya yang ada atau yang timbul dari sesuatu (orang, benda) yang ikut membentuk watak kepercayaan atau perbuatan seseorang."

Sedangkan pengertian pengaruh menurut Badudu dan Zain (1994: 1031) yaitu sebagai berikut:

" Pengaruh adalah (1) daya yang menyebabkan sesuatu yang terjadi, (2) sesuatu yang dapat membentuk atau mengubah sesuatu yang lain, dan (3) tunduk atau mengikuti karena kuasa atau kekuatan orang lain".

Dari pengertian yang telah dikemukakan sebelumnya dapat disimpulkan, bahwa pengaruh merupakan suatu daya yang dapat membentuk atau mengubah sesuatu yang lain. Sehubungan dengan adanya penelitian yang dilakukan oleh penulis, pengaruh merupakan bentuk hubungan sebab-akibat antar variabel. Dalam hal ini teknik jigsaw memberikan pengaruh dalam upaya peningkatan kemampuan berbicara bahasa Inggris.

\section{Hakikat Blended Learning}

1. Konsep Blended Learning

Isitlah Blended Learning (BL) sudah digunakan oleh lembaga pendidikan, khususnya perguruan tinggi. Akan tetapi masih banyak orang merasa bingung dengan isitlah tersebut. Banyak orang bertanya ketika mendengar tentang BL, "what is being Blended?" Meskipun ada beberapa perbedaan yang mendefinisikan BL, banyak definisi mempunyai banyak kesamaan atau menggunakan isitlah yang umum, yakni kata mengkombinasikan (combining). Definisi-definsi tersebut bisa terlihat seperti di bawah ini (Graham, Allen, and Ure, 2003: 217):

a. Combining instructional modalities (or delivery media);

b. Combining instrusctional methods; dan

c. Combining online and face to face instruction.

Definisi ketiga menurut Graham (2005: 78) lebih akurat merefleksikan sejarah penggabungan sistem Blended Learning dan merupakan fondasi yang akan dia kerjakan, yakni "Blended learning systems combine face-to-face instruction with computer-mediated instruction".

Menurut Graham (2005: 82) Blended Learning mempunyai dua tipe lingkungan pemblajaran, yakni ada lingkungan pembelajaran tatap muka secara tradisional (traditional face to face learning environment) yang masih digunakan di sekitar daerah pedesaan ataupun sekolah yang belum menggunakan teknologi; dan distributed learning environment yang sudah mulai berkembang seiring dengan teknologi-teknologi baru yang memungkinkan perluasan untuk mendistribusikan komunikasi dan interaksi.

Dahulu kedua lingkungan pembelajaran dalam Blended Learning tersebut tetap digunakan secara terpisah oleh karena menggunakan kombinasi media dan metode yang berbeda dan digunakan pada kebutuhan audien (peserta didik) yang berbeda. Misalnya tipe face-to-face learning terjadi dalam 
teacher-directed environment dengan interaksi person-to-person dalam live synchronous (pembelajaran langsung bergantung waktu) dan lingkungan yang highfidelity. Sedangkan sistem distance learning menekankan pada selfpaced learning dan pembelajaran dengan interaksi materi-materi yang terjadi dalam asynchronous (tidak tergantung waktu) dan lingkungan low-fidelity (hanya teks).

Pada zaman sekarang istilah Blended Learning sudah pada tahapan penggabungan kedua lingkungan di atas, tidak terpisah lagi, artinya ada saat pembelajaran menggunakan metode, media dan audien yang sama, yakni dengan menggunakan pembelajaran berbasis web. Hal yang berbeda dengan istilah BL pada masa yang akan datang, karena pada masa yang akan datang sistem blended akan lebih mendominasi dalam sebuah pembelajaran daripada blended sekarang. Artinya face to face learning secara tadisional akan semakin ditinggalkan karena teknologi terus berkembang yang tidak hanya terjadi di perkotaan, tetapi juga di daerah pedesaan. Sehingga ketika teknologi masuk desa, sistem pembelajaran tadisional yang ada akan semakin tenggelam dengan membudayanya lingkungan pembelajaran yang dimediasi oleh teknologi komputer dan internet.

Ada 3 alasan kenapa menggunakan Blended Learning (Graham, Allend dan Ure, 2003: 49), yakni, (1) improved pedadogy; (2) increased access and flexibility; and (3) increased cost-effectiveness. Oleh karena itu menurut Downing dan Chim (2004: 39) pembelajaran berbasis web dianggap sebagai metode instruksi yang efektif.
Meskipun demikian, alasan efektifitas dalam pembelajaran berbasis webnya tergantung dari beberapa faktor. Salah satu faktornya adalah mengintegrasikan desain user interface dengan desain instruksional.

"...many of these approaches still lack two important considerations needed for implementing learning applications based on Web; (1) integration of the user interface design with instructional design, and (2) development of the evaluation framework to improve the overall quality of web-based learning environments." (Nam and Jackson, 2007)

Ada tiga model desain instruksional dalam pembelajaran berbasis web yaitu: Objectivist Instructional Design Model (OIDMs); Constructivist Instructional Design Model (CIDMs), dan Mixed approach to Instructional Design (MID). Akan tetapi dari ketiga model desain instruksional tersebut tidak ada yang membahas isu yang terlibat dengan desain user interface dan efektifitas lingkungan berbasis web. Ketiga model tersebut menurut Nam dan Jackson (2007: 352) didasari oleh desain instruksional tradisional yang salah satunya model desain instruksional Dick and Carey.

Berdasarkan isu di atas maka pendidik memerlukan sebuah alat pembelajaran atau platform yang efektif untuk menampilkan materi pelajaran secara online dalam pembelajaran berbasis web. Banyak sekali platform yang dijual yang sudah teruji keefektifannya, seperti WebCT, Blackboard. Selain itu ada juga platform yang open source, 
yakni Moodle (The International Federation of Surveyor, 2010: 86). Moodle ini yang lebih terkenal di Indonesia yang bisa didesain untuk local internet atau online. Moodle (Modular Object-Oriented Dynamic Learning Environment) merupakan Course Management System (CSM), juga dikenal sebagai Learning Managment System (LMS) atau Virtual Learning Environmental (VLE), (Pusdiklat UPI, 2010: 51). LMS ini menggunakan teknologi internet untuk mengatur interaksi antara pengguna dan sumber pembelajaran, yakni web (Rivai dan Murni, 2009: 453).

Namun, dengan seiring perkembangan web. Banyak orangorang yang telah menciptakan jejaring sosial, yang bisa dimanfaatkan untuk melakukan pembelajaran ini. Contohnya Facebook, guru dapat membuat group di dalam facebook yang berfungsi untuk memudahkan pembelajaran blended learning.

2. Dukungan Teoritis dan Empiris

Berdasarkan beberapa studi sebelumnya Blended Learning ini lebih fokus pada pengembangan kognitif, maka teori yang mendasarinya adalah aliran terori belajar kognitif yang menjelaskan aspek aspek perkembangan kognitif menurut Piaget yaitu tahap (1) sensory motor; (2) pre operational; (3) concrete operational dan (4) formal operational.

Menurut Piaget, bahwa "Belajar akan lebih berhasil apabila disesuaikan dengan tahap perkembangan kognitif peserta didik. Peserta didik hendaknya diberi kesempatan untuk melakukan eksperimen dengan obyek fisik, yang ditunjang oleh interaksi dengan teman sebaya dan dibantu oleh pertanyaan tilikan dari guru. Guru hendaknya banyak memberikan rangsangan kepada peserta didik agar mau berinteraksi dengan lingkungan secara aktif, mencari dan menemukan berbagai hal dari lingkungan".

Implikasi teori perkembangan kognitif Piaget (Dimyati dan Mudjiono(2006: 273) dalam pembelajaran adalah :

a. Bahasa dan Cara berfikir anak berbeda dengan orang dewasa. Oleh karena itu guru mengajar dengan menggunakan bahasa yang sesuai dengan cara berfikir anak.

b. Anak-anak akan belajar lebih baik apabila dapat menghadapi lingkungan dengan baik. Guru harus membantu anak agar dapat berinteraksi dengan lingkungan sebaik-baiknya.

c. Bahan yang harus dipelajari anak hendaknya dirasakan baru tetapi tidak asing.

d. Berikan peluang agar anak belajar sesuai tahap perkembangannya.

e. Di dalam kelas, anak-anak hendaknya diberi peluang untuk saling berbicara dan diskusi dengan teman-temanya.

Salah satunya menggunakan Teori Belajar Konstruktivisme, Teori-teori baru dalam psikologi pendidikan dikelompok dalam teori pembelajaran konstruktivis (constructivist theories of learning). Teori konstruktivis ini menyatakan bahwa siswa harus menemukan sendiri dan mentransformasikan informasi kompleks, mengecek informasi baru dengan aturan-aturan lama dan merevisinya apabila aturan-aturan itu tidak lagi sesuai. Bagi siswa agar benar-benar 
memahami dan dapat menerapkan pengetahuan, mereka harus bekerja memecahkan masalah, menemukan segala sesuatu untuk dirinya, berusaha dengan susah payah dengan ide-ide. Teori ini berkembang dari kerja Piaget, Vygotsky, teori-teori pemrosesan informasi, dan teori psikologi kognitif yang lain, seperti teori Bruner (Slavin dalam Nur, 2002: 8).

Menurut teori konstruktivis ini, satu prinsip yang paling penting dalam psikologi pendidikan adalah bahwa guru tidak hanya sekedar memberikan pengetahuan kepada siswa. Siswa harus membangun sendiri pengetahuan di dalam benaknya. Guru dapat memberikan kemudahan untuk proses ini, dengan memberi kesempatan siswa untuk menemukan atau menerapkan ideide mereka sendiri, dan mengajar siswa menjadi sadar dan secara sadar menggunakan strategi mereka sendiri untuk belajar. Guru dapat memberi siswa anak tangga yang membawa siswa ke pemahaman yang lebih tinggi, dengan catatan siswa sendiri yang harus memanjat anak tangga tersebut (Nur, 2002:8).

3. Langkah-Langkah Blended Learning Blended Learning ini dircancang karena ada saat dimana siswa memerlukan face to face learning di samping web-based learning. Tidaklah heran mengapa siswa tidak memilih pembelajaran dengan keseluruhan lewat internet (distance learning), karena menurut Mayer (1979: 647),

"Pengajaran dengan modelmodel discovery bukanlah satusatunya cara untuk memudahkan siswa mengkonstruksi pengetahuan mereka sendiri. Metode langsung (direct method) yang telah dirancang dengan baik juga dapat membantu mereka membangaun pengetahuan." (Joyce, et. al., 2009: 14).

Ungkapan itu didukung oleh Luik (2006: 391) yang melakukan studi kepada murid-murid di Estonia yang memakai 4 fase untuk kesuksesan model instruksional dalam pembelajaran dari Alessi dan Trollip (2001: 221),

"model for successful instruction should involve four activities or phases of instruction: (1) presenting information; (2) guiding the learner; (3) practicing; dan (4) assesing learning." Selanjutnya mereka mengatakan, "since web-based learning could combine different types of educational software tutorials, hypermedia, simmulations, drills, etc it can foster any phase of instruction."

Berdasarkan fase-fase tersebut Luik (2006: 422) menemukan bahwa para siswa lebih memilih web-based learning pada fase 3 dan 4, yakni fase practicing dan assesing learning (drills, exercises, quizzes and/or tests), sedangkan fase 1 dan 2 lebih dipilih dengan face to face learning (teacher explanations).

Seperti yang telah dijelaskan sebelumnya bahwa Blended Learning ini mengijinkan kedua sifat pembelajaran yakni synchronous (bergantung pada waktu) dan asynchronous (tidak tergantung pada waktu). Pembelajaran yang bersifat synchronous bersesuaian dengan face to face learning, yakni waktu dimana siswa dan guru bertemu secara langsung di dalam kelas. Untuk pembelajaran yang bersifat asynchronous bersesuaian dengan pembelajaran berbasis web, dimana siswa dapat belajar dimanapun, 
kapanpun dan tidak harus bertemu dengan gurunya.

E-learning sering kali dibandingkan dengan pembelajaran tradisional yang menggunakan tatap muka (face to face). Tetapi pada prinsipnya akan lebih berarti ketika e-learning digunakan bersama-sama dengan pembelajaran tradisional untuk meningkatkan efisiensi dan efektifitas proses belajar mengajar. Proses pembelajaran yang memadukan e-learning dengan pembelajaran tradisional melalui metode tatap muka disebut blended learning. Didalam blended learning, digunakan dalam berbagai fungsi yang dapat meningkatkan proses pembelajaran, di antaranya:

a. Mempersiapkan proses pembelajaran secara tatap muka.

b. Memberikan fasilitas agar peserta didik dapat belajar lebih dalam tentang suatu pokok bahasan/topic.

c. Menyediakan media alternatif lain selain buku yang dapat diakses dimanapun.

d. Menyediakan media untuk interaksi di luar kelas, antara pendidik dan peserta didik, baik melalui forum, chating ataupun email.

e. Melalui LMS manajemen proses belajar dan mengajar dapat di kelola dengan memanfaatkan TIK sehingga pengelolaan dapat lebih efektif dan efisien.

Model Blended Learning ini pada dasarnya merupakan gabungan keunggulan pembelajaran yang dilakukan secara tatap-muka dan secara virtual. Menurut Semler (2005: 863):

"Blended learning combines the best aspects of online learning, structured face-to-face activities, and real world practice. Online

\begin{abstract}
learning systems, classroom training, and on-the-job experience have major drawbacks by themselves. The blended learning approach uses the strengths of each to counter the others' weaknesses."
\end{abstract}

Untuk materi menulis teks fungsional pendek dilakukan dengan metode ceramah dan diakhir pertemuan siswa akan diajak untuk mempraktikan tata cara menulis teks fungsional pendek yang baik dan tepat (face-to-face learning). Untuk menjelaskan konsepnya dilakukan dengan keduanya, yanki dalam faceto-face learning materinya disampikan di kelas dengan menggunakan web (memberikan informasi materi, demonstrasi, dan bekerja mandiri atau kerja kelompok serta penggunaan program power point dengan bantuan media komputer). Untuk web-based learning, materi bisa diupload dalam web atau mendapatkan sendiri atau secara berkelompok dengan mengeskplor sebanyak mungkin informasi tentang materi ini melalui link-link yang desediakan dalam web tersebut atau melalui searching dan browsing sendiri, lalu memberikan komentar pada topik yang diberikan oleh guru pada template "forums" di sebuah web yang dimiliki oleh guru tersebut.

\section{Hakikat Menulis (Writing) \\ Pengertian Menulis}

Menulis adalah menyampaikan ide atau gagasan dan pesan dengan menggunakan lambang grafik (tulisan). Tulisan adalah suatu sistem komunikasi manusia yang menggunakan tanda-tanda yang dapat dibaca atau dilihat dengan nyata. 
Tagiran (dalam Agus Suriamiaharja, 1996:1), mengembangkan bahwa:

"Menulis adalah menurunkan atau melukiskan lambang-lambang grafik yang menggambarkan suatu bahasa yang di pakai oleh seseorang, sehingga orang lain dapat membaca lambang-lambang grafik tersebut kalau mereka memahami bahasa dan gambaran grafik tersebut".

Sedangkan Robert Lodo (dalam Agus Suriamiaharja, 1996:18), mengatakan bahwa:

"Menulis adalah menempatkan simbol-simbol grafik yang menggambarkan suatu bahasa yang di mengerti oleh seseorang, kemudian dapat dibaca oleh orang lain yang memahami bahasa tersebut beserta simbol-simbol grafiknya".

Dalam buku "Language Files", Linguistic' Department of the Ohio State University (1982: 141), dikatakan bahwa, "Writing is the representation of language using visual symbol or characters, made with physical materials which allow linguistic messages to be preserved overtime". Pendapat serupa juga dikemukakan oleh Aundrey L. Reylolds (1983: 4) dalam buku "Exploring Written English $A$ Guide for Basic Writers" bahwa, "Writing is a Way to Discover new thoughts and new ideas".

Menulis merupakan kegiatan yang produktif dan ekspresif, karena dalam menulis terdapat aturan-aturan tata bahasa dan struktur bahasa serta pemilihan kata yang sesuai, seperti yang dikemukakan oleh Veronika Diptoadi (2009: 38) dalam buku "Becoming $A$ Creative Teacher", bahwa "Writing requires students to use grammar and vocabulary in order to clearly and correctly express what they want to say".
Definisi ini juga sejalan dengan yang diungkapkan oleh Larry Walter dalam bukunya " A Theoritical Model for Teaching Student to Write” (1983: 17), bahwa "Writing is the application of aggregate of grammatical rules, lexical item and rethorical pattrn that are needed an individual to produce a finish text”. John Harris (1993: 64) juga berpendapat bahwa "Writing is often as a means of practicing the grammar, vocabulary and disources structure of the largest language, particularly where the target language is a medium of instruction in the education system, or more commonly in higher education.

Proses menulis merupakan suatu kegiatan yang secara umum terdiri dari perencanaan (planning), yaitu merencanakan apa yang ingin disampaikan oleh penulis, garis besar penulisan (drafting), yaitu membuat konsep atau garis besar tentang apa yang ingin disampaikan, peninjauan (revising), yaitu meninjau kembali apa yang akan disampaikan oleh penulis kepada pembaca, dan perbaikan (editing), yaitu memperbaiki tulisan yang akan disampaikan kepada pembaca sehingga hasil tulisan tersebut dapat dinikmati dengan baik. Proses ini seperti yang diungkapakan oleh Jack $C$. Richards dan Willy A. Renandya (2002: 315) bahwa "The writing process as a privat activity may be broadly seen as comparising four mainstages: planning, drafting, revising and editing".

Dari empat keterampilan berbahasa, keterampilan menulis merupakan kemampuan yang paling kompleks. Keterampilan menulis tidak didapatkan secara otomatis melainkan harus dipelajari secara sadar melalui latihan-latihan mandiri atau terpimpin, teratur dan berkesinambungan. Menurut Hofferman and Lincon (1990:3) "No one learn to write automatically, writing is a means of communacation you must 
conciously learn". Hal ini dikarenakan dalam kegiatan menulis siswa harus mampu memadukan kosakata- kosakata yang tepat dan struktur-struktur kalimat yang benar sehingga siswa mampu membuat tulisan yang dapat dipahami dengan baik.

Dari uraian tersebut dapat disimpulkan bahwa menulis adalah kemampuan seseorang dalam melukiskan lambang-lambang grafik untuk menyampaikan ide atau gagasan yang dapat dimengerti orang lain dan menulis merupakan bagian dari kehidupan yang tidak terlepas dari kegiatan yang dialami berdasarkan ide, pemikiran, perasaan serta pendapat yang ingin disampaikan penulis kepada pembaca yang memerlukan latihan agar orang lain dapat memehami isi tulisan seorang penulis dengan baik.

\section{Hakikat Teks Fungsional Pendek}

Functional Text adalah teks khusus yang berisi perintah, pengarahan, sesuatu yang harus dilakukan atau tidak boleh dilakukan yang dapat berupa larangan (prohibition), undangan (invitation), pesan singkat (short message), daftar belanja (shopping list), peringatan (notice), pengumuman (announcement), dan lain-lain yang mengandung makna dan digunakan dalam komunikasi sehari-hari.

\section{Hakikat Hasil Belajar}

Hasil belajar adalah nilai yang menggambarkan tingkat pemahaman siswa setelah mengikuti pelajaran. Hasil belajar, untuk sebagian adalah berkat tindak guru, suatu pencapaian tujuan pengajaran. Pada bagian lain, merupakan peningkatan kemampuan mental siswa. Hasil belajar tersebut dibedakan menjadi dampak pengajaran, dan dampak pengiring. Dampak pengajaran adalah hasil yang dapat diukur, seperti tertuang dalam angka rapor, angka dalam ijazah, atau kemampuan meloncat setelah latihan. Dampak pengiring adalah terapan pengetahuan dan kemampuan di bidang lain, suatu transfer belajar (Dimyati dan Mudjiono, 2006: 167).

Istilah hasil belajar berasal dari dua kata yaitu "hasil" dan "belajar". Dalam kamus bahasa Indonesia kata hasil berarti sesuatu yang menjadi akibat dari usaha. Sedangkan kata belajar mempunyai banyak pengertian seperti yang telah dijelaskan sebelumnya. Jadi dapat disimpulkan bahwa hasil belajar adalah sesuatu atau akibat yang diperoleh dari suatu usaha yang telah dilakukan/dialami oleh seseorang (siswa) yang dituangkan dalam bentuk kecakapan, kecerdasan, keterampilam dan tingkah laku.

Hasil belajar merupakan hasil dari suatu interaksi tindak belajar dan tindak mengajar. Ditinjau dari sisi guru, tindak mengajar diakhiri dengan proses evaluasi hasil belajar. Ditinjau dari siswa, hasil belajar merupakan berkhirnya penggal dan puncak proses belajar (Dimyati, 2002: 54).

Hasil belajar pada hakekatnya merupakan suatu perubahan perilaku yang terjadi pada diri peserta didik. Pada umunya hasil belajar akan memberikan pengaruh dalam dua bentuk : (1) peserta didik akan mempunyai perspektif terhadap kekuatan dan kelemahannya atas perilaku yang diinginkannya; (2) mereka mendapatkan bahwa perilaku yang diinginkan itu telah meningkat baik setahap atau dua tahap, sehingga timbul lagi kesenjangan antara penampilan perilaku yang sekarang dengan perilaku yang diinginkan (Mulyasa, 2006: 267)

Dengan diadakannya penilaian, maka siswa dapat mengetahui sejauh mana telah berhasil mengikuti pelajaran yang diberikan oleh guru atau seberapa besar pemahaman siswa terhadap suatu materi pelajaran tersebut. Hasil penilaian yang diperoleh guru akan dapat 
mengetahui siswa-siswa mana yang sudah berhak melanjutkan pelajarannya karena sudah menguasai materi, maupun mengetahui siswa-siswa mana yang belum berhasil menguasai materi. Hal ini tentu saja dapat diketahui dengan melihat hasil belajar siswa. Hasil belajar siswa tersebut dapat diketahui dengan memberikan tes yang dibuat khusus oleh peneliti setelah proses pembelajaran berlangsung.

Dengan hasil belajar yang diperoleh guru akan mengetahui apakah metode serta media yang digunakan sudah tepat atau belum. Jika sebagian besar siswa memperoleh angka jelek pada penilaian yang diadakan, mungkin hal ini disebabkan oleh pendekatan atau metode dan media yang digunakan kurang tepat. Apabila demikian halnya, maka guru harus mawas diri dan mencoba mencari metode dan media lain dalam mengajar. Hasil belajar juga merupakan cerminan kualitas sutau sekolah (Arikunto, 2005: 111).

Pendapat-pendapat tersebut dapat disimpulkan bahwa hasil belajar adalah kemampuan keterampilan, sikap dan keterampilan yang diperoleh siswa setelah ia menerima perlakuan yang diberikan oleh guru sehingga dapat mengkonstruksikan pengetahuan itu dalam kehidupan sehari-hari.

\section{METODE PENELITIAN}

Penelitian dilaksanakan pada siswa kelas VII selama 4 bulan dimulai dari bulan Oktober sampai dengan bulan Januari sedangkan pengumpulan data di lapangan dilakukan pada bulan November 2011 di SMPN 98 Jakarta Selatan sebagai tempat penelitian.

Berdasarkan judul dan permasalahan, di atas maka jenis penelitian ini adalah quasi eksperimen. Dalam penelitian ini, siswa dibedakan atas dua kelas yaitu kelas kontrol dan kelas eksperimen. Kedua kelas ini diberi perlakuan yang berbeda. Pada kelas eksperimen digunakan model pembelajaran Blended Learning, sedangkan kelas kontrol digunakan pembelajaran konvensional di sekolah tersebut.

Disain eksperimen yang digunakan dalam penelitian ini berbentuk post-test only control design group. Responden benar-benar dipilih secara random dan diberi perlakuan, untuk lebih jelasnya dapat dilihat pada tabel.

Tabel 3.1 Desain Eksperimen

\begin{tabular}{|l|c|l|}
\hline Group & Perlakuan & Post-tes \\
\hline (R) Eksperimen & $T_{1}$ & $\mathrm{O}_{1}$ \\
\hline (R) Kontrol & & $\mathrm{O}_{2}$ \\
\hline
\end{tabular}

keterangan:

$\mathrm{O}_{1} \quad$ : Postes pada kelas eksperimen

$\mathrm{O}_{2} \quad$ : Postes pada kelas kontrol

$T_{1}$ : Perlakuan dengan penggunaan model Blended Learning

Akhir dari pengajaran, siswa pada dua kelompok tersebut diberi tes dengan soal yang sama. Hasil tes dari kedua kelompok tersebut dijadikan sebagai data penelitian, kemudian dianalisis dan dibandingkan untuk melihat adanya pengaruh pengajaran menggunakan metode yang berbeda terhadap hasil belajar teks fungsional pendek bahasa Inggris. Perbedaan perlakuan antara kelas eksperimen dan kelas kontrol hanya pada penggunaan metode belajar, sedangkan materi pembelajarannya tetap sama.

\section{HASIL DAN PEMBAHASAN}

Berdasarkan penelitian di lapangan diketahui kesulitan - kesulitan dalam menulis teks fungsional pendek bahasa inggris di SMPN 98 Jakarta Selatan adalah kurangnya pemahaman siswa terhadap ciri-ciri teks fungsional 
pendek yang baik, kurangnya kosa kata bahasa Inggris yang siswa hafal, dan kurangnya pemahaman tentang susunan kalimat yang benar.

Namun dengan menggunakan metode blended learning, guru dapat mengurangi kesulitan-kesulitan yang dialami oleh karena mereka bisa belajar tidak hanya dengan membaca buku tetapi dapat melalui web yang sudah disediakan oleh guru. Sehingga dapat dilihat bahwa kemampuan siswa yang menggunakan teknologi blended learning lebih baik dari pada siswa yang hanya belajar dengan metode konvensional. Meningkatnya kemampuan menulis siswa ini tidak luput dari hal-hal yang mempengaruhinya seperti perkembangan teknologi yang pesat seperti internet, karena mereka bisa mengakses kembali materi yang telah disampaikan guru di sekolah. Hal itulah yang membuat mereka lebih aktif dalam upaya peningkatan kemampuan siswa dalam menulis teks fungsional pendek bahasa Inggris.

Berdasarkan pada pengujian hipotesis diperoleh nilai $t_{\text {hitung }}=5.08$ pada taraf signifikan $\alpha=0.05$, dengan derajat kebebasan $n_{x}+n_{y}-2$ dan nilai $t_{\text {tabel }}=1.669$. Kemudian kedua nilai tersebut dibandingkan dan hasilnya yaitu nilai $t_{\text {hitung }}$ lebih besar dari nilai $t_{\text {tabel }}$ $(5.08>1.669)$. Hal ini berarti bahwa hipotesis $H_{a}$ diterima yaitu "Ada pengaruh yang signifikan terhadap penggunaan teknologi pembelajaran Blended Learning terhadap hasil belajar menulis teks fungsional pendek Bahasa Inggris pada siswa kelas VII SMPN 98 Jakarta Selatan" dan hipotesis nol $\left(H_{o}\right)$ ditolak yaitu "tidak ada pengaruh yang signifikan terhadap penggunaan teknologi pembelajaran blended learning terhadap hasil belajar menulis teks fungsional pendek Bahasa Inggris pada siswa kelas VII SMPN 98 Jakarta
Selatan. Dengan demikian guru dapat menggunakan teknologi pembelajaran blended learning dalam kegiatan belajar mengajar, karena teknologi pembelajaran ini berpengaruh untuk meningkatkan hasil belajar menulis bahasa Inggris.

\section{SIMPULAN}

Berdasarkan pada hasil penelitian dan pengujian persyaratan hipotesis, maka penulis dapat menyimpulkan beberapa hal dari hasil penelitian ini. Adapun kesimpulannya adalah:

1. Penggunaan teknologi blended learning memiliki pengaruh yang signifikan terhadap hasil belajar menulis bahasa Inggris, ini dibuktikan dari hasil uji $-\mathrm{t}$ pada taraf signifikan $\alpha=0.05$ diperoleh $t_{\text {hitung }}=5.08$ dan $t_{\text {tabel }}=1.669$ kemudian dibandingkan dan ternyata $t_{\text {hitung }}$ lebih besar dari nilai $t_{\text {tabel }}$ $(5.08>1.669)$ yang berarti terdapat pengaruh teknologi pembelajaran blended learning terhadap hasil belajar menulis teks fungsional pendek bahasa Inggris siswa kelas VII SMPN Jakarta Selatan.

2. Pada siswa yang diajarkan dengan menggunakan teknologi blended learning memberikan hasil belajar menulis teks fungsional pendek bahasa Inggris pada siswa kelas VII SMP Negeri 98 Jakarta Selatan tergolong baik, karena diperoleh nilai rata -rata $\overline{X_{1}}=73.8$ dengan median sebesar 81.85 dan modus sebesar 84. 3 serta nilai tertinggi sebesar 90 dan nilai terendah 55 .

Berdasarkan pada kesimpulan kesimpulan di atas, maka yang menjadi saran dari penulis adalah:

1. Penggunaan metode pengajaran dalam proses belajar harus disesuaikan dengan pokok bahasan 
yang akan diajarkan guru terhadap siswanya.

2. Penggunaan teknologi blended learning dapat dijadikan variasi dalam proses belajar, maka seorang pendidik dituntut untuk lebih aktif, kreatif dan inovatif.

3. Guru harus lebih menguasai metode yang digunakan dengan baik, disesuaikan dengan perkembangan dunia saat ini.

\section{DAFTAR PUSTAKA}

Akhadijah, S. (1997). Menulis Ilmiah. Jakarta: Universitas Terbuka.

Arikunto, S. (2003). Dasar-Dasar Evaluasi Pendidikan. Jakarta: Bumi Aksara.

Azwar, S. (1994). Reliabilitas dan Validitas edisi ketiga. Jogjakarta: Pustaka Pelajar.

Boettcher, J, V., Conrad, Rita-Marie . (2010). The Online Teaching Survival Guiding. San Fransisco: Jossey-Bass.

Chang, C. H. (2007). Engaging Learning through the Internet. Singapore, Prentice Hall Pearson Education South Asia Pte Ltd.

Departemen Pendidikan Nasional. (2001). Kamus Besar Bahasa Indonesia.

Jakarta: Balai Pustaka.

Departemen Pendidikan Nasional. (2003). Kurikulum 2004 SMA.. Jakarta: Direktorat Pendidikan Menengah Umum.

Dimyati dan Mudjiono. (2006). Belajar dan Pembelajaran. Jakarta: Rineka Cipta dan Departemen Pendidikan dan Kebudayaan.

Diptoadi, V. (2009). Becoming a Creative Teacher. Jakarta:
Reginal English Language

Office.

Djamarah, S. B. dan Zain, A. (2006). Strategi Belajar Mengajar. Jakarta: Rineka Cipta.

Ghozali, I. (2002). Aplikasi Multivariat dengan Program SPSS. Semarang: Badan Penerbit Universitas Diponogoro.

Harmer, J. (2008). How to Teach Writing. Edinburgh: Longman.

Harris, J. (1993). Introduction of Writing. London: Pinguin.

(1982). Language Files. Linguisics' Department of the Ohio State University.

Januszewski, A., Molenda, M. (2008). Educational Technology. New York and London: Lawrence Erlbaum Associate.

Joyce, B., Weil, M., Calhoun, E. (2009). Models of Teaching. Pearson Education. USA

Nasution. (2008). Metode Research. Jakarta: Bumi Aksara.

Reynold, L. A. (1983). Exploring Written English a Guide for Basic Writers. Boston, Toronto: Litle. Brown and Company. Ltd.

Richards,C.J. dan Willy A. R. (2002). Methodologi in Language Teaching: An Anthology of Current Practice. Cambridge's University Press.

Sabarti, A. (1997). Menulis. Jakarta: Depdikbud

Suriamiharja, A, dkk. (1997). Petunjuk Praktis Menulis. Jakarta :Depdikbud.

Sudjana, N. (2004). Penilaian Hasil Proses Belajar Mengajar. Jakarta: Rosda. 
Sudjana, N. (1995). Penilaian Hasil Proses Belajar Mengajar. Bandung: Remaja Rosdakarya.

Sudjana. (1996). Metode Statistika. Bandung: Tarsito

Sugiyono. (2008). Metode Penelitian Kuantitatif, Kualitatif dan $R \& D$. Jakarta: Alfabeta

Tarigan, H.G. (2008). Menulis Sebagai Suatu Keterampilan. Berbahasa. Bandung: Angkasa.

Tarigan, H. G. (1985). Membaca sebagai Suatu Keterampilan Berbahasa. Bandung: Angkasa.

Trianto (2007).

Model-model pembelajaran inovatif berorientasi Konstruktivistik Jakarta : Prestasi Pustaka.

Warsita, B. (2008). Teknologi Pembelajaran: Landasan dan Aplikasinya. Jakarta: Rineka Cipta.

Walter, L. (1983). A Theoritical Model for Teaching Student to Write.

Wardiman, A, d.k.k. (2008). English in Focus 1 : for Gade VII Junior High School (SMP/MTS). Jakarta: Pusat Perbukuan, Departemen Pendidikan Nasional.

\section{internet:}

Dziuban Charles D.; Hartman, Joel L.; dan Moskal, Patsy D. 2004. Blended Learning. (http://net.educause.edu/ir/librar y/pdf/ERB0407.pdf). Diakses pada tanggal 05 Oktober 2011.
Graham, Charles R. 2005. Blended Learning Systems. (http://media.wiley.com/product data/excerpt/86/07879775/078 7977586.pdf) . Diakses pada tanggal 06 Oktober 2011.

Luik, P .2006. Web Based-Learning or Face-to-Face Teaching Preferences of Estonian Students. (www.aare.edu.au/06pap/lui061 59.pdf). Diakses pada tanggal 12 Oktober 2011.

Pengertian Pesan Singkat. (http://idkf.bogor.net/yuesbi/eD U.KU/edukasi.net/SMP/B.Indon esia/Menulis.Pesan.Singkat//). Di akses pada tanggal 23 oktober 2011.

Pengertian kalimat Larangan. (http://www.sekolahoke.com/20 11/09/cara-membuat-kalimatlarangan-dalam.html). Diakses pada tanggal 23 oktober 2011.

Sudrajat, A. 2008. Penilaian Hasil Belajar (Online) (http://let's talk about edication.html). Diakses tanggal 2 januari 2010.

Tsai, Susana dan Machado, Paula .2010. E- Learning, Online Learning, Web-Based Learning or Distance Learning Unveiling the Ambiguity in Cureent Terminology. (http://www.eleranmag.org/subp age.cfm?section $=$ best_practices\&article $=6-1$ ). Diakses pada tanggal 15 oktober 2011. 